\title{
The Rule of Law and the Extraordinary Situation
}

\author{
András Karácsony ‘ ${ }^{\circledR}$, Szabolcs Nagypál" \\ * Professor, Eötvös Loránd University, Faculty of Law and Political Sciences, Department of \\ Legal and Social Theory, e-mail: karacsony@ajk.elte.hu \\ ** Head of the Law School, Mathias Corvinus Collegium (MCC); Assistant Professor, Eötvös \\ Loránd University, Faculty of Law and Political Sciences, Department of Legal and Social \\ Theory, e-mail: nagypalszabi@ajk.elte.hu
}

\begin{abstract}
The various legal theorists dealing with the operation and effect of law have mostly examined situations that can be described as occurring in the usual, regular, normal state of social life. Over the last half century, and particularly since the formation and later enlargement of the European Union, the requirement of the rule of law has emerged as a key topic. The test of the rule of law is as follows: it is necessary to examine in an abnormal situation or, as it were, in an extraordinary situation exactly how it is possible to take political decisions that are of fundamental importance to society while also guaranteeing that these decisions remain within the rule of law at all times.

The aim of this study is to investigate how and by what constitutional mandate the Hungarian Government deviated from the normal constitutional situation in 2020. The "state of exception" theorised by Carl Schmitt and Giorgio Agamben means the suspension of the law. It is important to understand their views in order to see that the Hungarian situation in 2020 is utterly dissimilar to such a state of exception. In short, we need to distinguish a state of exception from an extraordinary situation, because the latter does not imply the suspension of law in general or, more specifically, the suspension of the rule of law, but that parliamentary and government decisions remain within it. The special legal order applied in an extraordinary situation is not in fact a suspension of democracy, still less of the rule of law. On the contrary, it actually falls within both: in a state of national crisis, this situation is democracy itself and the rule of law itself, and - accordingly - strict laws (both democratic and imposed within the rule of law), or rather laws of cardinal importance, make its conditions and its functioning possible and regulate it.
\end{abstract}

Keywords: rule of law, extraordinary situation, state of exception, Carl Schmitt, Giorgio Agamben, pandemia

\section{Introduction}

The various legal theorists dealing with the operation and effect of law have mostly examined situations that can be described as occurring within the usual, regular, normal state of social life. In such circumstances, society is not in the throes of revolution, civil 
war, or other horrors and disasters. In short, life proceeds in the normal and usual way. Over the past century and a half, legal and political thinkers have not only analysed the state of law but have also formulated various requirements for the way that law operates. In this regard, the requirement to establish and maintain the legal state (Rechtsstaat) and the rule of law has been set up quite specifically. ${ }^{1}$ The legal state, as the phrase implies, is not only about the law, but also about the state.

Over the last half century, and particularly since the formation and later enlargement of the European Union, the requirement of the rule of law has emerged as a key condition. The test of the rule of law is as follows: it is necessary to examine in an abnormal situation or, as it were, in an extraordinary situation exactly how it is possible to take political decisions that are of fundamental importance to society while also guaranteeing that these decisions remain within the rule of law at all times. The shocking experience of the past few months, dominated by the epidemic threat, shows that various misunderstandings and unfounded assumptions of one kind or another are held by the general public. The objective of this paper, which focuses primarily on the Hungarian situation, is to show, that even this extraordinary situation can be managed and controlled within the normal framework of the rule of law.

\section{The state of national crisis is not a state of exception}

The epidemic has shown how well governments in European countries were able to respond quickly and effectively to the ever-changing problems they have faced. The general expectation, of course, was that government policy in this particular, special situation should be consistent with what is permitted within the framework of the rule of law. However, criticisms have been levelled at Hungary (such as Donald Tusk's comment in Der Spiegel about the Hungarian Prime Minister [Müller \& Puhl, 2020] that the German legal and political thinker Schmitt, who is known to have been unafraid of the state of exception and to have been a fervent supporter of Adolf Hitler in the early years of the National Socialist regime, would have been proud of Viktor Orbán) which demonstrate either a complete lack of knowledge of the actual circumstances or an expression of mere political antipathy.

The aim of the study is to shed light on how and by what constitutional mandate the Hungarian Government deviated from the normal constitutional situation in 2020. It is worth clarifying a few concepts at the beginning of this inquiry. In doing so, we shall draw on various works by Schmitt and related studies by Agamben. Both thinkers have analysed historical and political situations in which the normal, ordinary world of law does not prevail; more specifically, they have discussed extraordinary or exceptional situations. Schmitt wrote a hundred years ago, whereas Agamben continues to work today. Because of the long-lasting influence they have had, they are both classics in this field.

The relationship between the concepts of the legal state and the rule of law (differences and similarities) will not be discussed in this paper. 
In the normal state (when the normal course of life is not disrupted by natural disasters or political and military crises affecting countries), the normal functioning of the legal system provides security through predictability. However, there are situations - outside the normal situation - where the traditional formal legal requirements are not sufficient to ensure the safe protection of life, but where the emergency itself must be addressed first and foremost. The security of a society can be threatened not only by armed conflict, but also by a natural disaster or, as the case may be, an epidemic. A health problem on a massive scale can be as serious as a multitude of violent actions on the streets. In anticipation of such a situation, the constitutional order of states which function under the rule of law provides for the legal possibility of deviating from the normal situation. It should be emphasised that it is only possible to deviate from the normal legal situation in a legally regulated manner. As such, the confrontation with extraordinary situations, while modifying the normal order of law-making, is still part of the overall functioning of the rule of law.

Schmitt examined how the state of law deviates from the normal state in relation to the question of sovereignty. Two of his books address this in detail: one, Dictatorship (Die Diktatur, 1921), which examined the history of ideas on the question of sovereignty; the other, Political Theology (Politische Theologie, 1922). In his 1921 work, he described two types of dictatorship, one based on pouvoir constitué (constitutional power) and the other on pouvoir constituant (constituent power): the commissar (i.e. the dictator entrusted with a specific task) and the sovereign dictator. The distinction is based on the following question: what can guarantee the enforcement of the given norms and how can a new norm be created?

The commissarial dictator always starts from the existing constitutional order and seeks to implement such constitutional order in a situation where the application of constitutional procedures does not ensure the existence of a constitutional order accepted by the political community. In this state of exception, his task is to restore the normal legal (i.e. constitutional) situation. This kind of dictatorship is limited by time. Schmitt gave the example of the Roman Republic, when it was the task of the dictator, elected for one year, to bridge the gap or conflict between the norms of law and the norm of law enforcement (the implementation of law) in the face of a serious external threat, by making political decisions to resolve the emergency. In short, the commissar-like dictator suspends the constitution in order to defend that same constitution. Schmitt compared this situation to a state of siege.

In contrast, the sovereign dictator does not simply suspend an existing, specific constitution based on the law, but seeks, by its suspension, to create a situation in which a new constitutional order becomes possible. His activity is characterised by the pouvoir constituant, or constituent power. The pouvoir constituant knows only rights, but not obligations; a pouvoir constitué, on the other hand, knows only obligations and not rights. The relationship between pouvoir constituant and pouvoir constitué is captured by Schmitt in a parallel analogy with nature, as the difference between natura naturans (nature that creates) and natura naturata (nature that is created). What the two types of dictatorship analysed by Schmitt have in common, however, is that the possibility of each occurring is legally regulated, and both aim to create a constitutional state of 
normality. The first does this by reinforcing the old status quo, the second by creating a new one.

Less than a year later, Schmitt's book on political theology appeared, in which there was no mention of the commissar at all, only of the sovereign. One might suppose that the author had radicalised his position on both the sovereign and, in line with this, the state of exception. The very first sentence of the work - 'Sovereign is he who decides on the state of exception' - has since been quoted countless times (Schmitt, 2005, p. 5). Schmitt here focused on the final decision, i.e. the decision that cannot be deduced from the legal norm (this alone shows his departure from the rule of law principle). Underlying all this was his conviction that the state (politics) takes precedence over the law. The end of the legal order does not mean the end of all orders, as there is the order of the state (politics).

Incidentally, we wish to note that it is here that Schmitt's dispute with Hans Kelsen lies, as Kelsen interpreted the state order only in the context of legal regulation, and analysed only the normal situation of life. For Schmitt, the sovereign's power originates in itself; it is not derived from something else, nor is it a power deduced from some norm. However, this sovereign is no longer the same as the sovereign dictator formulated a year earlier, because that type of dictator was tied to the constitutional situation, whereas this sovereign is no longer tied. The sovereign therefore stands alone, with only the power behind it by which it can act as sovereign, and the suspension of the existing legal order is the end point of its potential for power. In essence, in the state of exception there is no legal order; there is only the order established by political will.

What did Agamben (2004) add to Schmitt's thoughts on sovereignty? He made it clear that the state of exception is a situation where, on the one hand, there are effective laws that are not applied and, on the other hand, there are actions that have no place under the laws. They have power, but not the force of law. The state of exception, simply put, is a no-man's land. The no man's land lying between public law and political facts, between the legal order and life. It is therefore a borderline situation, not just for the individual, but also for the community.

It is not only totalitarian regimes which are characterised by the introduction of a state of exception. In the same way, according to Agamben, the Patriot Act passed on 26 October 2001 and the other related provisions have created a state of exception in the United States of America, which, among other things, has made it possible to detain people considered suspicious for many years without judicial review. This is of course a rather paradoxical situation, since the law itself regulates the suspension of fundamental rights. The state of exception is therefore a phenomenon where life and law are in conflict, i.e. where the decision-making domains of law and politics diverge.

\section{Constitutional principles of the special legal order in Europe and in Hungary}

What does all this have to do with the state of national crisis introduced in Hungary as a response to the epidemiological emergency? In short: nothing. In Schmitt's view, 
a state of exception is always a state of lawlessness, where only political power is manifested, whereas the Hungarian state of national crisis was introduced on the basis of the constitutional order. ${ }^{2}$ However, it was precisely to make this difference clear that it was necessary to recall the interpretation of the Schmittian state of exception, to show how wrong it is to equate the decisions taken in this epidemic situation with the state of exception.

Having examined the different theoretical approaches to law (the ideas of Schmitt and Agamben) that have paid particular attention to the operation of law in a nonnormal situation, it is now worth briefly examining the constitutional framework of the Hungarian legal response to the threat of epidemic. This will clearly show that the handling of the situation has not reached even close to a level which could be called a state of exception; in other words, the country has remained fully within the rule of law. It is important to note that the core of the criticisms and doubts concern the relationship and correlations between the special legal order and human rights. Perhaps one of the decisive theoretical foundations to be taken into consideration is that the special legal order itself is not in fact a kind of suspension of (liberal) democracy (the people's rule), still less of the legal state and the rule of law but, on the contrary, it is part of both. In a state of national crisis, this new situation is democracy itself and the rule of law itself, and - accordingly - strict laws (both democratic and imposed within the rule of law), or rather laws of cardinal importance, make its conditions and its functioning possible and regulate it.

In international (public) law, two main groups of human rights can be distinguished. ${ }^{3}$ On the one hand, there are human rights that cannot be restricted in any respect, even in a special legal order, and which can therefore be considered absolute and retain the highest priority, as a minimum requirement of constitutionality. ${ }^{4}$ The International Covenant on Civil and Political Rights, adopted by the United Nations (UN) in 1966, highlights seven such human rights. These are included in the group of rights that cannot be subject to restrictions pursuant to Article 4(2).

Two of the four 1949 conventions that are part of the so-called Geneva Conventions and which predate the international law developed by the UN, namely the third convention on prisoners of war and the fourth on the status and protection of civilians (both dated 12 August 1949), contain similar provisions. Furthermore, both of the 1977 Additional Protocols (both dated 8 June 1977) give priority to certain human rights: the first Additional Protocol provides for the protection of victims of international armed conflicts; the second Additional Protocol contains various legal provisions on the protection of certain victims of non-international armed conflicts, i.e. civil wars.

The currently effective Hungarian Fundamental Law (the country's constitution) defines the following rights as inalienable rights: the right to life and buman dignity; the prohibition of torture, inhuman and degrading treatment or punishment;

\footnotetext{
A sophisticated contemporary press analysis comes to the same conclusion (Techet, 2020).

For example, András Jakab's study provides an overview of the German constitutional law, which is a model for Europe (Jakab, 2007).

4 Doctoral dissertations are also being written on the theoretical systematisation of regulations made under special legal order see, for example, Mészáros, 2017.
} 
the prohibition of slavery and trafficking in human beings; the prohibition of medical or scientific experimentation without voluntary consent; the prohibition of human selective breeding or the use of the human body or parts of the human body for profit and furthermore the prohibition of human cloning; the presumption of innocence (presumptio innocentic); the right of defence; the principle of "no crime without law" (nullum crimen sine lege); and the prohibition of multiple convictions. ${ }^{5}$

On the other hand - and the vast majority of human rights fall precisely into this category - there are also human rights that cannot be regarded as unrestrictable by definition. For instance, in case of a conflict (i.e. collision) between human rights, the necessity and proportionality (fundamental rights) tests guide the (possibly reciprocal) restriction. ${ }^{6}$ The exercise and enjoyment of these human rights and their enforcement may therefore be suspended in a special legal order, even beyond the limits allowed by the necessity and proportionality tests. ${ }^{7}$ The key feature of this is the temporary nature, however. $^{8}$

Constitutional law must always strike a balance (although of course it will never be, nor can it be, a perfect one) between, on the one hand, ensuring that the protection against a given threat is secure and implemented by swift and effective measures, ${ }^{9}$ and on the other hand, protecting fundamental rights in a constitutional democracy and the rule of law. The proportionality requirement ensures that the resulting concentration of power is limited to what is strictly necessary.

The extraordinary legal order was introduced into the Hungarian constitutional order in 1989, and its effects are still felt today. Compared to the two previous authoritarian regimes, it is therefore a legal achievement of the democratic transition and the establishment of the rule of law. ${ }^{10}$ In the new Fundamental Law of 2012, a separate chapter is devoted to the special legal order - now bearing a slightly changed name - which refers to the current Defence and Disaster Management Act (2011. évi CXXVIII. törvény a katasztrófavédelemröl és a hozzá kapcsolódó egyes törvények módosításáról) in terms of detailed rules. In the Hungarian Fundamental Law, the qualified periods were supplemented in 2016 with rules on the protection of internal security, i.e. rules to be followed in the event of a terrorist emergency, in response to the growing international threat of terrorist acts.

The regulation of the special legal order can be regarded as very sophisticated in the Hungarian system, if compared to other regulatory practices, for example in Europe. In many countries, no distinction is made at constitutional level between different types of emergency. Currently there are six types of emergencies in Hungary: state of national crisis, state of emergency, state of preventive defence, state of terrorist threat, unexpected

\footnotetext{
On the question of fundamental rights and their limitations in English see Kiss, 2013.

6 The necessity and proportionality test, for example, provides a constitutional safeguard in times of the special legal order (Mógor \& Horváth, 2009).

7 The restrictions on fundamental rights were already essentially the same in principle in the previous constitution see Kiss, 2008.

8 All measures must be of a temporary nature see Kádár, 2014.

9 This fundamental contradiction (dilemma) of special legal orders is well summarised in the study by Barnabás Kiss (Kiss, 2018).

10 For an analysis of the development of Hungarian constitutional law see Szabó \& Horváth, 2012.
} 
attack and state of extreme danger. ${ }^{11}$ The type of emergency just introduced in relation to the epidemic is the mildest of these. ${ }^{12}$ The promulgator is the Parliament in the first four cases and the Government in the last one, whereas there is no promulgation in case of an unexpected attack. In the last four cases, extraordinary measures may be taken by the Government, in the first case by the Defence Council, and in case of a state of emergency by the President of the Republic.

It can be seen that, in terms of the structure of the state, the principle of separation of powers will temporarily change, and a temporary concentration of power may occur for practical reasons. Once the emergency is over, this must be restored to its original state, and in the meantime strong checks and balances must be built in (primarily by the National Assembly and the Constitutional Court).$^{13}$

In the first six months of 2020, the Covid-19 epidemic fundamentally tested the European states and showed in practice the level of response and ability to react to various crisis situations in each country, including the legislative framework, the institutional system and infrastructure, and also the coordinating political leadership which brings nations together (Sándor, 2020a). Obviously, the extent of the threat to basic needs was such that state intervention was urgently needed, beyond the means normally available under the legal system. The fact that there is no uniform name for the different modes and types of special legal order in the European Union has made comparison between the various approaches applied in different European states considerably more difficult (Sándor, 2020b). In addition to legal incompetence and journalistic sloppiness, translation difficulties have often contributed to misunderstandings (Kelemen, 2019).

A fundamental characteristic of crisis situations is the need to step outside the normal legal framework and systems of everyday life and to provide quick and decisive responses and reactions, which is what the institution called the state of national crisis provides. ${ }^{14}$ In such cases, a natural tension is created between security and freedom: one could label this as a paradox of the rule of law, when the legal mandate or authority must be both sufficiently detailed and at the same time provide sufficient freedom to act (Csink, 2017). As is evident from this review, the state of national crisis introduced in Hungary because of the epidemic has nothing to do with the state of exception coined by Schmitt. The latter means the suspension of the law, whereas the solutions applied now were based on the constitutional order, the legal order. This means, simply put, that the critical references to Schmitt, to dictatorship and to the dissolution of Parliament simply have nothing to do with reality.

To summarise, the extraordinary legal order in Hungary is 'a constitutional state, not a state of unconstitutionality' (Koja, 2003). To put it another way, it is not the end of the legal state (or the rule of law), but - despite the extreme challenges facing the country and the state - precisely the celebration of it.

\footnotetext{
11 A typological analysis of the six periods can be found in Jakab \& Till, 2016.

12 A short summary analysis of the measures introduced is also available in English in Szilvay, 2020.

13 For a review of the safeguards and guarantees see Till, 2019.

${ }^{14}$ Of course, the reasons behind the restrictions of the extraordinary legal order always reveal some political philosophy see Fődi, 2020.
} 


\section{References}

Agamben, G. (2004). Ausnahmezustand. Suhrkamp.

Csink, L. (2017). Mikor legyen a jogrend különleges? Iustum Aequum Salutare, 13(4), 7-16.

Fődi, K. (2020, April 10). Nekem kéne feláldozni magam, vagy mások áldozzák fel magukat értem? 444. Online: https://444.hu/2020/04/10/nekem-kene-felaldozni-magam-vagy-masok-aldozzak-fel-magukat-ertem

Jakab, A. (2007). A szükségállapot alapvető dilemmája és jogi természete a német alkotmányjog és irodalom tükrében. Jogtudományi Közlöny, 62(2), 39-49.

Jakab, A. \& Till, Sz. (2016). A különleges jogrend. In L. Trócsányi \& B. Schanda (Eds.), Bevezetés az alkotmányjogba (pp. 485-513). HVG-Orac.

Kádár, P. (2014). A kivételes hatalomtól a különleges jogrend idején bevezethető intézkedésekig. Katonai Jogi és Hadijogi Szemle, 2(1), 5-46.

Kelemen, R. (2019). A különleges jogrend szabályozása az egyes alkotmányokban I. Általános alapvetés, fogalmi elhatárolás. Magyar Katonai Jogi és Hadijogi Társaság. Vélemények a Katonai Jog Világából, 1.

Kiss, B. (2008). Az alapjogok korlátozása és a közérdek. In K. Szamel (Ed.), Közérdek és közigazgatás (pp. 169-182). MTA JTI.

Kiss, B. (2013). Some remarks on the provisions of the new fundamental law of Hungary regarding fundamental rights. In R. Keča (Ed.), Harmonizacía srpskog i mađarskog prava sa pravom Evropske Unie (pp. 513-523). Pravni fakultet u Novom Sadu, Centar za izdavačku delatnost.

Kiss, B. (2018). Az alapjogok korlátozhatósága különleges jogrendben, különös tekintettel a (büntető-) igazságszolgáltatásra vonatkozó rendkívüli intézkedésekre. In M. Homoki-Nagy et al. (Eds.), Ünnepi kötet dr. Nagy Ferenc egyetemi tanár 70. születésnapjára (pp. 555-556). SZTE ÁJTK.

Koja, F. (2003). Állami szükségállapot és a szükségállapotra vonatkozó jog. In P. Takács (Ed.), Államtan (pp. 797-817). Szent István Társulat.

Mészáros, G. (2017). Különleges helyzetek és beavatkozási lehetőségek az alkotmányos demokráciákban [Doctoral dissertation, Debreceni Egyetem Marton Géza Állam- és Jogtudományi Doktori Iskola].

Mógor, J. \& Horváth, L. (2009). Alkotmányos korlátok (garanciák) a minősített időszakokról szóló szabályozásban. Bolyai Szemle, 18(3), 35-45.

Müller, P. \& Puhl, J. (2020, April 21). What the Economy Needs Is a Blitzkrieg. Interview Conducted by Peter Müller and Jan Puhl. Spiegel. Online: www.spiegel.de/international/europe/donald-tusk-what-theeconomy-needs-is-a-blitzkrieg-a-382b2e03-3f48-412c-9973-9a883e913f5e

Sándor, L. (2020a, April 13). A szükséghelyzet nemzetközi. Beszélgetés Federica Cristanival. Mandiner. Online: https://precedens.mandiner.hu/cikk/20200413_a_szukseghelyzet_nemzetkozi

Sándor, L. (2020b, September 15). „Nincsen egységes mintája a különleges jogrendnek”. Beszélgetés Szilágyi János Edével. Mandiner. Online: https://precedens.mandiner.hu/cikk/20200915_nincsen_egyseges_ mintaja_a_kulonleges_jogrendnek_beszelgetes_szilagyi_janos_edevel

Schmitt, C. (2005). Political Theology. Four Chapters on the Concept of Sovereignty. Trans. by G. Schwab. University of Chicago Press. Online: https://doi.org/10.7208/chicago/9780226738901.001.0001

Szabó, Cs. \& Horváth, L. (2012). Magyarország Alaptörvényének és a Magyar Köztársaság Alkotmányának összevetése a különleges jogrend vonatkozásában. Hadmérnök, 7(2), 395-404.

Szilvay, G. (2020, April 17). The nature of Hungary's state of emergency'. The European Conservative. Online: https://europeanconservative.com/2020/04/the-nature-of-hungarys-state-of-emergency

Techet, P. (2020, April 8). Tényleg Carl Schmittet kell olvasni, hogy megértsük a járványhelyzetet? Azonnali. Online: https://azonnali.hu/cikk/20200408_tenyleg-carl-schmittet-kell-olvasni-hogy-megertsuk-ajarvanyhelyzetet

Till, Sz. (2019). Különleges jogrend. In A. Jakab \& B. Fekete (Eds.), Internetes Jogtudományi Enciklopédia (IJOTEN). Online: http://ijoten.hu/szocikk/kulonleges-jogrend 